\title{
A Mobile Application to Guide Healthcare Professionals in the Correct Technique for Personal Protective Equipment Use During the COVID-19 Pandemic
}

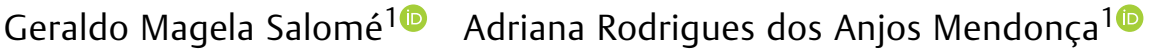 \\ Marcus Vinicius Teixeira de Almeida1 ${ }^{10}$ Flávio Dutra Miranda1(1) \\ 1 Professional Master's Program in Applied Health Sciences, \\ Universidade do Vale do Sapucaí, Pouso Alegre, MG, Brazil \\ J Coloproctol 2021;41(4):383-392 \\ Address for correspondence Geraldo Magela Salomé, RN, PhD, \\ Universidade do Vale do Sapucaí, Pouso Alegre, MG, Brasil \\ (e-mail: salomereiki@yahoo.com.br).
}

\begin{abstract}
Objectives The present study aimed to develop an application to guide healthcare professionals on using personal protective equipment (PPE) during the COVID-19 pandemic and prevent and treat skin lesions caused by these devices.

Methods This is a study on technological production. The framework for application development consisted in the following phases: Phase 1-“Design: identification of application development requirements;" Phase 2-“Application prototype development": including an integrative literature review in major databases; Phase 3-"Application construction": elaboration of the decision tree, algorithm, database structuring, and software development; Phase 4- "Transition": application functionality test.

Result Our application Simplifica EPI is an innovative technology; this software is a tool to assist healthcare professionals in using PPE. In addition, it describes how to prevent and care for skin lesions caused by PPE. Simplifica EPI has 25 screens and 32

Keywords

- COVID-19

- pandemic

- personal protective equipment images. It will be available on the Google Play Store after its registration with the Brazilian National Institute of Industrial Property.

Conclusions After an integrative literature review, the application Simplifica EPI was developed as an innovative technology with great potential for use by healthcare professionals.
\end{abstract}

\section{Introduction}

COVID-19 transmission occurs by respiratory secretions and saliva. Recommended precautions to avoid contamination and transmission to other individuals include covering your mouth when coughing or sneezing, washing your hands regularly, and avoiding touching your face, especially your eyes, nose, and mouth. ${ }^{1,2}$

During the COVID-19 pandemic, healthcare professionals are at an increased risk of contamination due to the frequent need to perform procedures. In addition, subsequent received

November 13, 2020 accepted after revision June 15, 2021
DOI https://doi.org/

10.1055/s-0041-1739372.

ISSN 2237-9363. (c) 2021. Sociedade Brasileira de Coloproctologia. All rights reserved.

This is an open access article published by Thieme under the terms of the Creative Commons Attribution-NonDerivative-NonCommercial-License, permitting copying and reproduction so long as the original work is given appropriate credit. Contents may not be used for commercial purposes, or adapted, remixed, transformed or built upon. (https://creativecommons.org/ licenses/by-nc-nd/4.0/)

Thieme Revinter Publicações Ltda., Rua do Matoso 170, Rio de Janeiro, RJ, CEP 20270-135, Brazil 
complications can increase virus spread after several procedures, including tracheal aspiration and intubation.

Healthcare professionals need to strictly observe the precautions standardized by the Brazilian Ministry of Health to minimize transmission. Personal protective equipment (PPE) is recommended to all healthcare professionals working with these patients in health institutions, regardless of their suspected or confirmed diagnosis., 3

Personal protective equipment are all devices for individual use intended to protect the physical integrity of the worker, such as gloves, goggles, face or respiratory protectors, aprons, and lower limbs protectors. Hand hygiene is critical to prevent virus contamination and spread.

Prolonged or incorrect use of face masks, respirators, and goggles/visors results in constant frictional forces and pressure on tissues, leading to injuries, including in professionals performing funeral procedures. ${ }^{5}$

Educational technologies, including applications, video games, and online courses, could provide appropriate information about PPE techniques for healthcare professionals. This technology can also teach preventive actions and therapeutic procedures for pressure injuries caused by an inappropriately used PPE. With this technology, healthcare professionals could provide safe assistance with no risk to the patient while avoiding contamination and preventing facial skin lesions caused by PPE misuse.

Computer technologies in education and health have been innovating the teaching-learning and theory-practice relationships in healthcare because they adapt to safe patient care requirements and contemporary educational models. Healthcare professionals are following up on this innovation, showing that the interactivity provided by virtual learning favors the educational process and the provision of safe care without harm to the patient. ${ }^{6-9}$

The present research is part of a project to develop a mobile application for healthcare professionals on PPE use with preventive actions and therapeutic approaches to pressure injuries caused by these medical devices. Thus, with this technology, healthcare professionals will provide safe, damage-free assistance with no risk to the patient while avoiding contamination and preventing facial skin lesions caused by misused PPE.

The present study aimed to develop an application to guide healthcare professionals in using PPE and to indicate preventive measures for injuries caused by these devices.

\section{Methods}

This is a study on technological production based on software engineering from the methodological development research type.

The present study was approved by the Research Ethics Committee of the Faculdade de Ciências da Saúde Dr. José Antônio Garcia Coutinho (opinion number 4.230.375).

The Simplifica EPI application used the methodology relevant to Contextualized Instructional Design, which involves a constructivist proposal. This methodology consists of the intentional action of planning, developing, and applying specific didactic situations, incorporating mecha- nisms that favor contextualization. ${ }^{10}$ The construction of the application followed the steps described as shown in -Figure 1.

\section{First Step: Analysis}

After an integrative literature review, research development delimited the following: theme identification and selection of the research question; establishment of inclusion and exclusion criteria for studies; definition of information to be extracted from selected studies and study categorization; the evaluation of studies included in the integrative review; results interpretation and review presentation; and synthesis of knowledge. ${ }^{11}$

The theme was "guiding healthcare professionals in PPE use and preventive measures for skin lesions (SLs) caused by these devices during the COVID-19 pandemic."

The objective was to answer the following question: "Which are the PPEs and how to use them correctly during the COVID-19 pandemic? What preventive measures are available in the literature to prevent skin lesions caused by inappropriate PPE use during the COVID-19 pandemic?"

The PICO strategy determined the appropriate question to solve this clinical issue. ${ }^{12}$ In this strategy, "P" is the population (healthcare professionals), "I" is intervention (how to use PPEs and prevent SLs); "C" is comparison (it does not apply to this study, since it is not comparative); and "O" refers to outcome (protocol as an application).

An integrative literature review was carried out in the following health sciences databases: Medical Literature Analysis and Retrieval System Online (MEDLINE), Scientific Electronic Library Online (SciELO), and Latin American and Caribbean Health Sciences Literature (LILACS).

Controlled descriptors in health sciences included COVID-19, Equipment and Supplies, and Personal Protective Equipment. The search strategy was based on different combinations, adopting the Boolean AND operator in Portuguese, Spanish, and English, depending on the database.

Paper selection adopted the following inclusion criteria: only primary studies directly connected to the theme, original articles available as full texts, published from 2015 to 2020.

Exclusion criteria included theses, dissertations, monographs, technical reports, articles unrelated to the proposed object of study (determined after abstract reading), and repeated papers.

The titles and abstracts were read independently by two authors to ensure that the texts contemplated the guiding question and met the established inclusion criteria. In case of doubt during selection, the decision was based on the complete analysis of the paper.

The level of evidence of the selected studies was classified according to the Agency for Healthcare Research and Quality, ${ }^{13}$ with six categories: Level 1 : evidence from metaanalysis of multiple randomized controlled clinical trials; Level 2: evidence from individual experimental studies; Level 3: evidence from quasiexperimental studies; Level 4: evidence from descriptive (nonexperimental) or qualitative studies; Level 5: evidence from case reports or experience; Level 6: evidence based on expert opinions. 


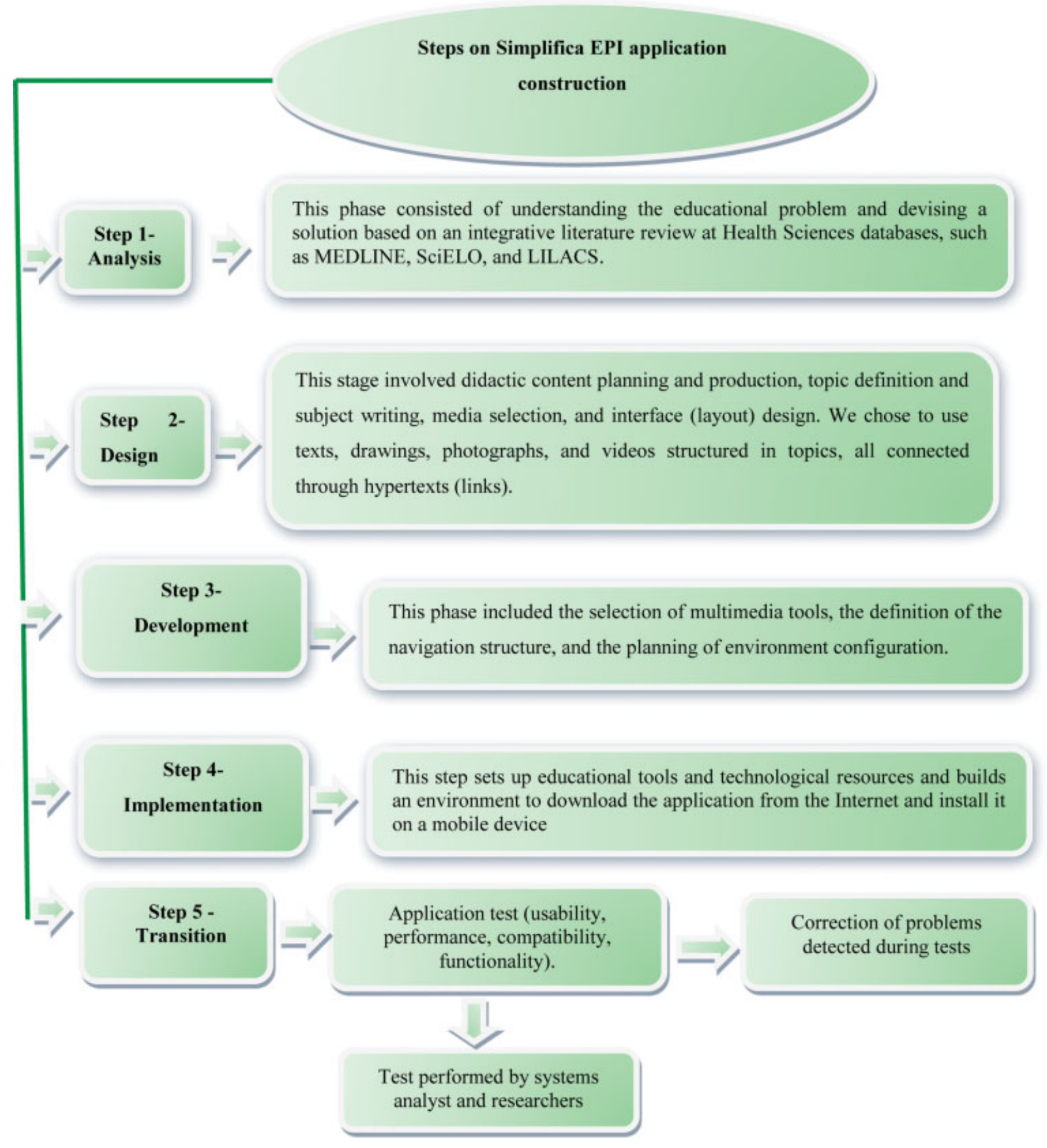

Fig. 1 Diagram of application construction steps.

\section{Second Step: Design}

This stage involved didactic content planning and production, topic definition and subject writing, media selection, and interface (layout) design. We chose to use texts, drawings, photographs, and videos structured in topics. The didactic contents covered in the application were the following:

\section{Phase 1-COVID-19 infection}

This phase consisted of information about COVID-19 definition, type, signs and symptoms, and preventive measures recommended by the World Health Organization (WHO).
Phase 2-Use of personal protective equipment by healthcare professionals during the COVID-19 pandemic

This phase defined PPEs, including those recommended by the WHO, to care for patients with COVID-19.

In addition, we describe well-defined instructions on PPEs donning and doffing during the clinical practice; these techniques must be carried out systematically to prevent these healthcare professional workers from contracting the infection and to prevent SLs resulting from their inappropriate use.

\section{Phase 3-Injuries caused by improper PPE use}

This phase defines a pressure injury caused by a medical device and the anatomical regions with the highest 
prevalence of lesions. In addition, it describes some measures (facial device types and use, cream use, barrier protectors, occlusive devices) to prevent and treat skin lesions associated with PPE.
Third Step: Development

This step selected application tools, defined navigation structure, and planned the environment configuration. A decision tree guided the professional systems analyst regarding the application construction, as shown in - Figure 2.

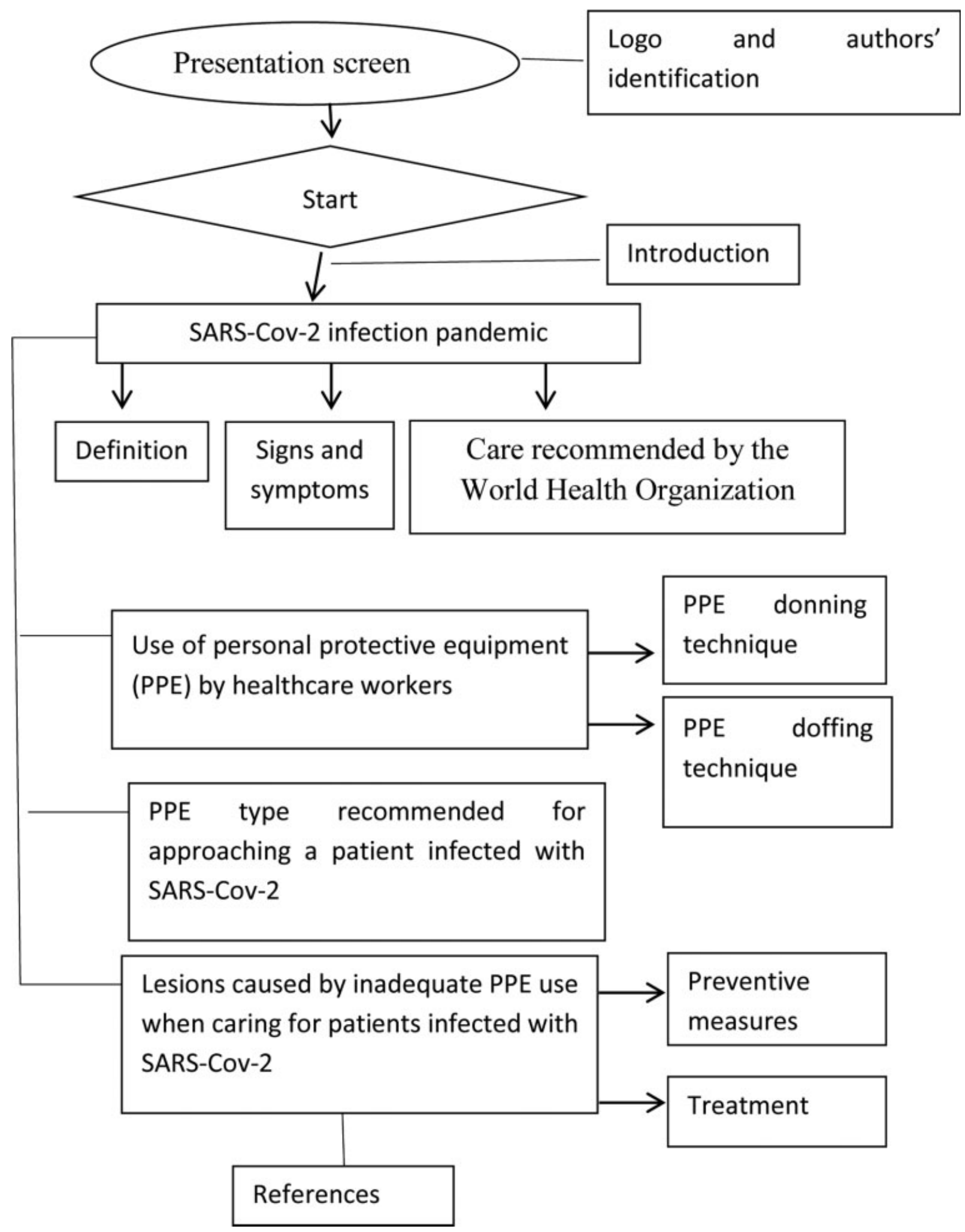

Fig. 2 Decision tree for application construction. 


\section{Fourth step: Implementation}

This step sets up educational tools and technological resources and builds an environment to download the application from the Internet and install it on a mobile device. The application will be available for free at the Play Store.

\section{Fifth Step: Transition}

This step consisted of functionality tests (usability, performance, compatibility, and functional tests). The testing process followed the steps outlined later.

Usability test: it determined if a user could use the software intuitively from the initial to the end screen. The authors of the project used the application five times, going through all screens.

Performance test: it evaluated the responsiveness to each command. The systems analyst and the authors of the project verified the application startup time, screen changes, and end time for each screen.

Compatibility with the theoretical framework test: this test consisted of two phases: the first one verified the information at the semantic and syntactic level of the software content, whereas the second one applied a functional or black box test. The systems analyst conducted this test.

The functional software testing was also performed in some devices with Android technology, characterized by mobile-type equipment and Wi-Fi for wireless network access to analyze usability and compatibility. The authors and the systems analyst conducted the entire testing process.

\section{Results}

\section{Integrative literature review}

Our first review identified 12,535 articles but excluded 4,523 due to duplicity. Next, we selected 8,012 papers based on the title and 163 for abstract reading. The final sample consisted of 112 articles for full-text analysis. Of these, 51 papers were excluded for not answering the guiding question, leaving 26 articles for application building. As such, from 12,535 papers, 26 were selected for algorithm development (-Figure $\mathbf{3}$ ).

The application developed in the present study is a hard technology (software), and it provides healthcare professionals with a tool to assist in PPE donning and doffing. In addition, it discusses how to prevent and care for PPE-related SLs. After registration with the Brazilian National Institute of Industrial Property, it will be available on the Google Play Store as Simplifica EPI.

The Simplifica EPI app has 25 screens and 32 images describing PPE donning and doffing and how to prevent PPErelated SLs. The first screen presents the identification of the authors and a summary of the subjects covered by the application. Clicking on the "SARS-Cov-2 infection pandemic" icon, the user obtains information on SARS-Cov-2 definition, signs, symptoms, and healthcare recommended by the WHO, as shown in -Figure 3.

Clicking on the "Use of personal protective equipment by healthcare professionals" icon, the user views the donning and doffing technique step-by-step (with description and photos), as shown in - Figure 4.

Clicking on the icon "Injuries caused by inappropriate PPE use when caring for patients with SARS-Cov-2," the user views the definition of pressure injury caused by medical devices and the anatomical regions with the highest incidence of lesions. In addition, it describes some measures (facial device types and use, cream use, barrier protectors, occlusive devices) to prevent and treat skin lesions associated with PPE, as shown in - Figures 5 and $\mathbf{6}$.

\section{Discussion}

When caring for patients with COVID-19, healthcare professionals need to make decisions and assist their patients with the least potential risk, with no harm to themselves or to their patients. Healthcare professionals must use PPE to protect themselves and their patients. Since they also must protect themselves from injuries caused by inappropriate PPE use, institutions must develop educational technology, such as applications, online courses, and video games supported by scientific evidence.

During the pandemic, the use of technologies in the educational and health areas has been innovating the teaching-learning and theory-practice relationships in care to prevent COVID-19 spread. The use of virtual environments for continuing education has shown that interactivity favors the learning process and improves care with no harm to professionals and clients. ${ }^{14,15}$

This application offers the technique of PPE donning and doffing and measures to prevent injuries caused by their inappropriate use, seeking to promote safe, quality care with no risk or damage to healthcare professionals and patients. The Simplifica EPI application can be a theoretical and practical tool in self-care, providing an environment for professionals or students to go through reflection and action cycles to promote safety assistance.

According to the Brazilian labor legislation, via the Regulatory Standard for Safety and Health at Work in Health Services, the employer must provide sufficient PPE, whether disposable or not, allowing the workers to perform their tasks safely. In addition to PPE supply, employers must ensure continuous training and worker protection whenever there is a change in exposure to biological agents. ${ }^{16}$

Since the COVID-19 pandemic required healthcare for severe cases, healthcare professionals are deemed a highrisk group for infection. In addition, inappropriate PPE use resulted in SLs. As these healthcare professionals are at the forefront of the response to the COVID-19 outbreak, they may be more vulnerable to contagion and illness. ${ }^{17}$

The implementation of strict protocols on the proper use of PPE, especially regarding PPE donning and doffing, to influence compliance by the health care team is a strategy to improve protection of those professionals against COVID19. In 2014, during the Ebola outbreak, the contamination of two healthcare professionals was probably associated with noncompliance with these protocols. One study found that approximately half of the healthcare professionals touched, 


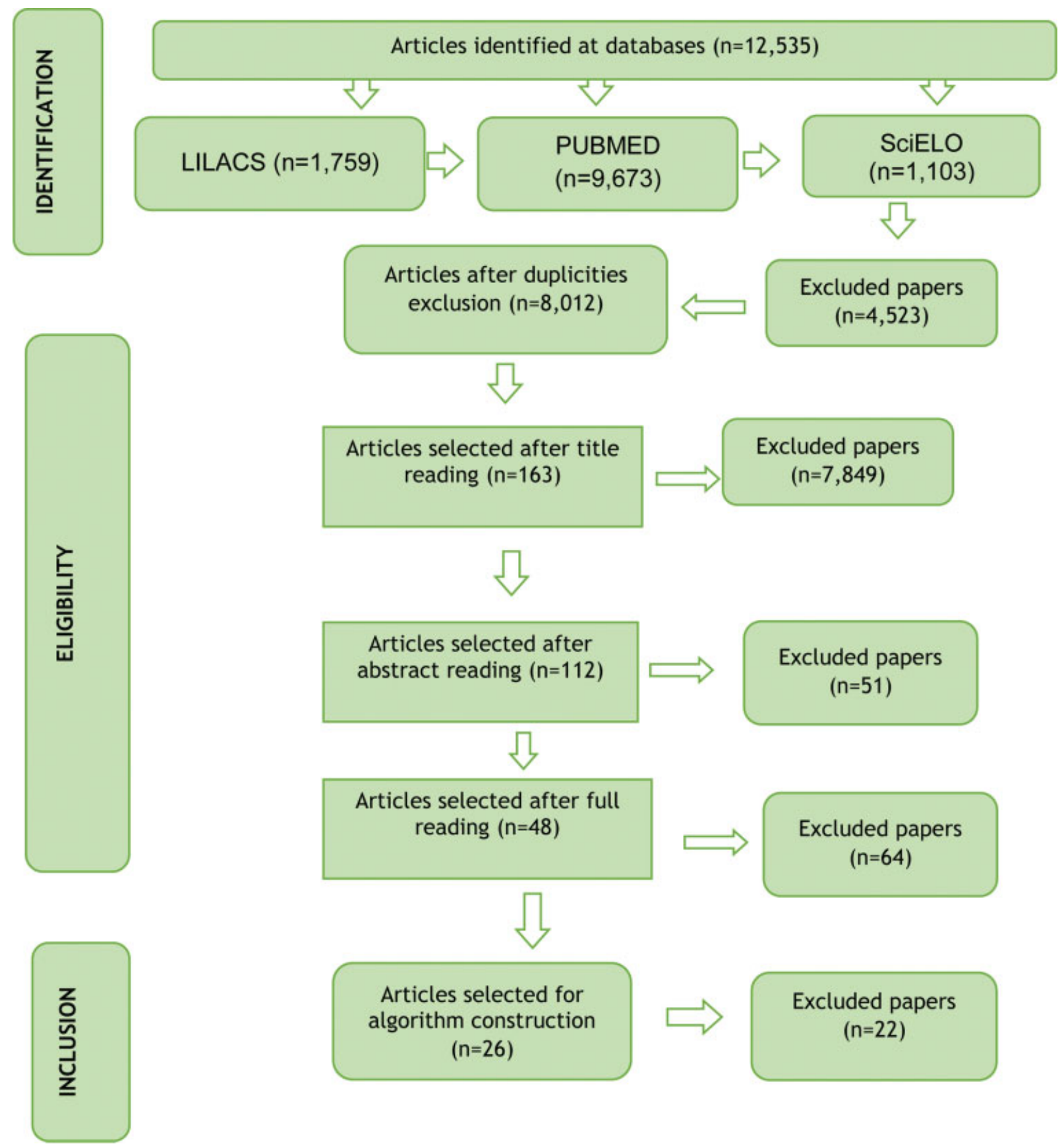

Fig. 3 Flowchart of the process of identification, selection, and inclusion of studies based on PRISMA recommendation. Pouso Alegre, MG, Brazil, 2020.

with no gloves, a potentially contaminated PPE surface; in addition, $\sim 26 \%$ inappropriately touched the front part of the mask, which highlights the inappropriate disposal of PPE. ${ }^{18,19}$

The screens of the Simplifica EPI application consist of simple images with accessible, clear vocabulary, and short texts on the techniques for PPE donning and doffing and measures to prevent SLs. Font type and size intent for harmonious aesthetics and clear content visibility to the user.
The text of an application must be easy to understand and promote the interest of the user. Content choice and presentation must consider its ability to trigger the prior knowledge of the students. ${ }^{20,21}$

As the main tool, figures and photos in an application must be clear, objective, and, mainly, pedagogical to favor a routine change and allow for several ways of learning a subject. These figures or photos must motivate the user, promote intuitive knowledge, and provide an understanding 


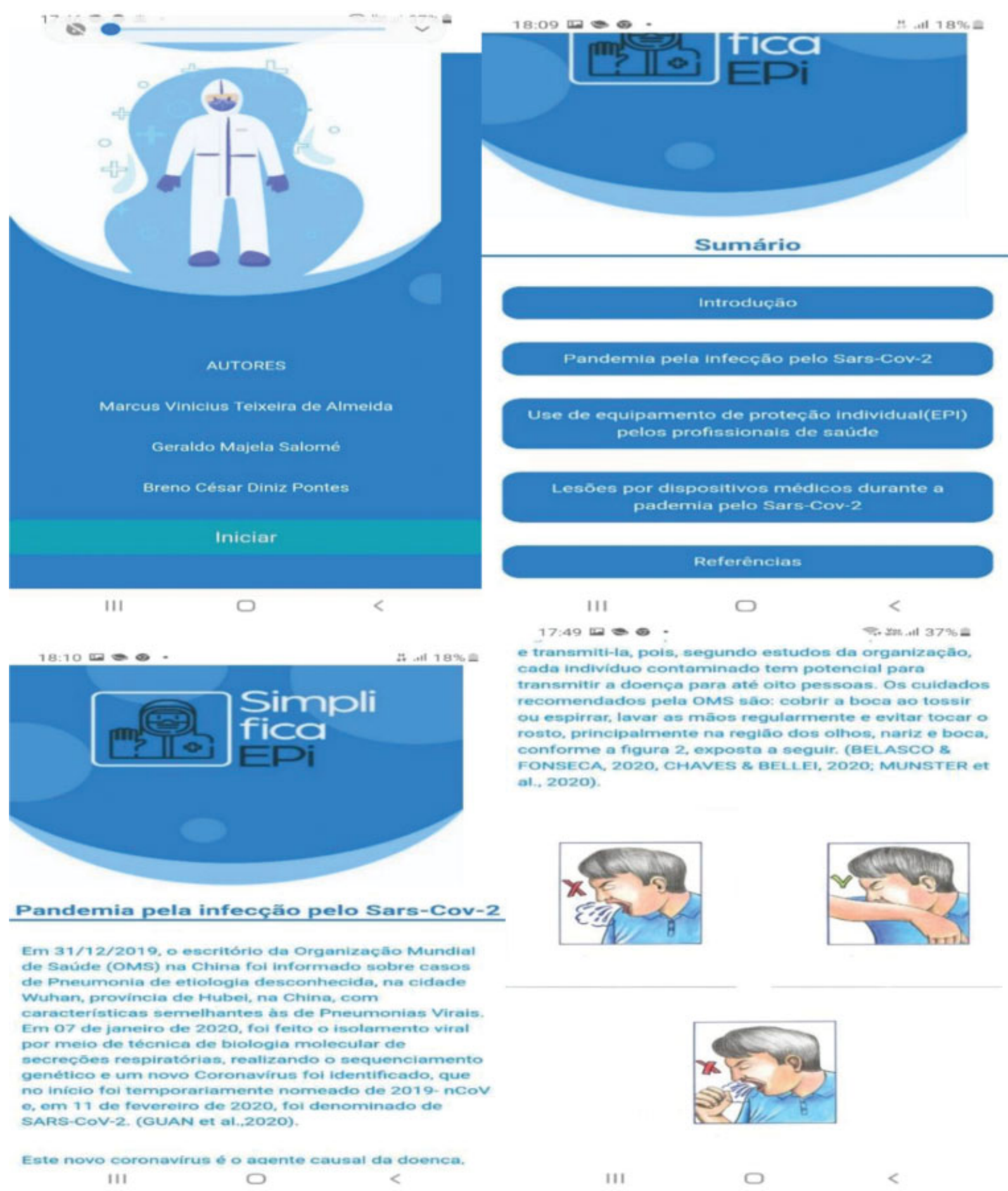

Fig. 4 Simplifica EPI application identification and summary screens. Pouso Alegre, MG, Brazil, 2020.

of concepts that would be more difficult to assimilate as text only. ${ }^{20-22}$

\section{Conclusions}

After an integrative literature review, the Simplifica EPI application was developed as an innovative technology with great potential for use by healthcare professionals. This tool demonstrates the correct technique for PPE donning and doffing. As a result, it can prevent COVID-19 contamination by healthcare professionals and its transmission to patients. It also offers measures to prevent the development of PPE-related injuries. In short, it aims for safe care with the least possible risk and no damage to healthcare professionals and patients. 
390 Mobile Application on Personal Protective Equipment Use Salomé et al.

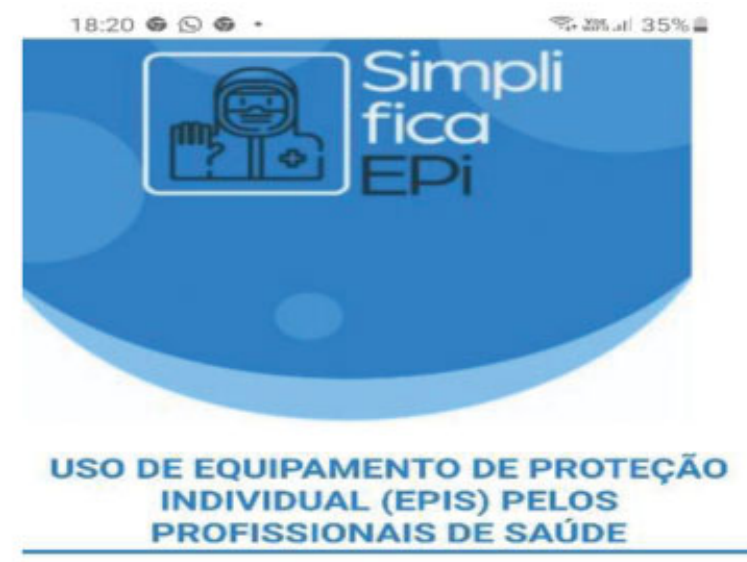

A NR-06 do Ministério do Trabalho, publicada no D.0.U PARTE I, DECRETO $n^{\circ} 46.237$ - de 18 junho de 1959, ou norma regulamentadora 6 , fol criada para regulamentar o uso de Equipamentos de Proteçẫo Individuais (EPIs), de modo que todas as empresas sejam obrigadas a adotar as mesmas medidas de proteçăo do funcionário em cenários semelhantes. Isso significa que todas as pessoas exercendo as mesmas funçōes devem ter um mesmo equiparnento de proteçăo padronizado que leve em consideração as normas legais exigidas para essa função em especifico.

$$
\text { III }
$$

$18: 37 \bullet \mathbf{0} \bullet$

$$
\text { 7. } 20.433 \%
$$

Técnica da colocação da máscara de proteção respiratória tipo N95, N99, N100, PFF2 ou PFF

- Segurar o respirador com o clip nasal próximo à ponta dos dedos, deixando as alças pendentes.

- Encaixar o respirador sob o queixo.

- Posicionar uma das alças na nuca e a outra na cabeça.

- Ajustar o clip nasal no nariz.

- Verificar a vedação pelo teste de pressẫo positiva e negativa.

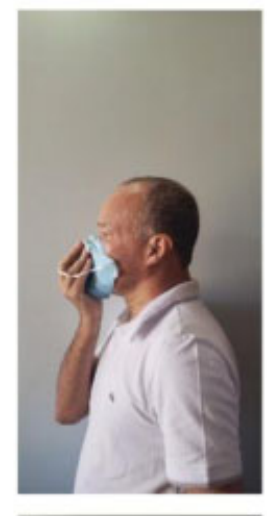

III

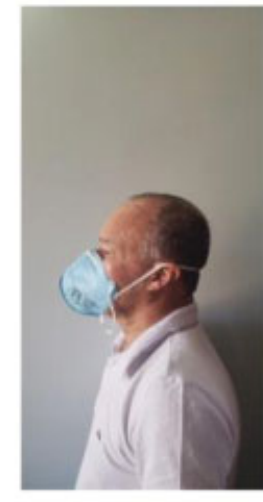

$<$
$18: 24 \mathbb{a} \mathbf{0}$

Técnica de colocação de óculos protetores e Face Shield

- Colocar os óculos sobre a face, deixando confortável. Os óculos devem ser de uso exclusivo para cada profissional responsável pela assistência.

- O Protetor Facial (Face Shield) deverá ser utilizado para os atendimentos e transportes de pacientes com sintomas respiratórios, suspeitos ou confirmados com Sars-CoV-2.

- 0 protetor facial deve ser de uso individual e cada profissional deve efetuar a higiene do seu equipamento após cada atendimento ou transporte.

- Os protetores faciais devem ser utilizados sobre as máscaras (máscara de proteçăo respiratória tipo N95, N99, N100, PFF2 ou PFF3) e sobre os óculos de proteçäo.

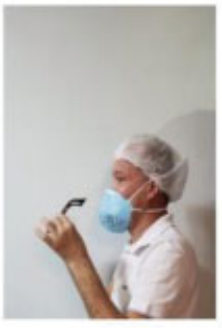

III

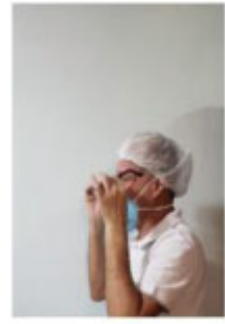

$<$
Máscara 7.

\section{Touca}

\section{PFF2 e PFF3}

Uso da luva

Recomendaçōes sobre o tipo de EPI.

Algoritmos

\section{Voltar}
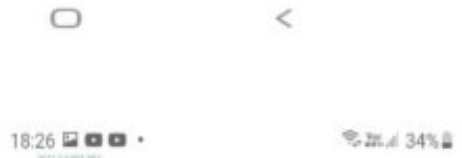

- Certifique-se de que o tronco esteja totalmente coberto, bem como os braços e os punhos.
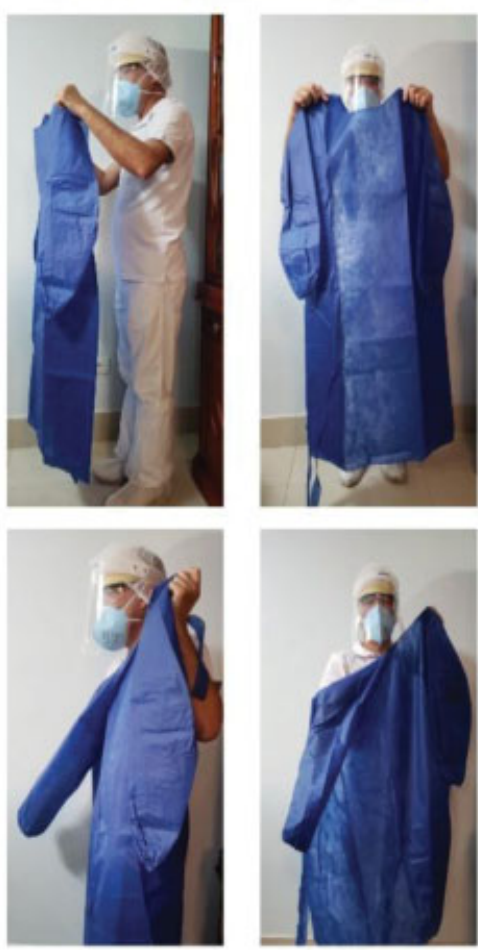

III

Fig. 5 Screens on personal protective equipment donning and doffing techniques for healthcare professionals. Pouso Alegre, MG, Brazil, 2020. 


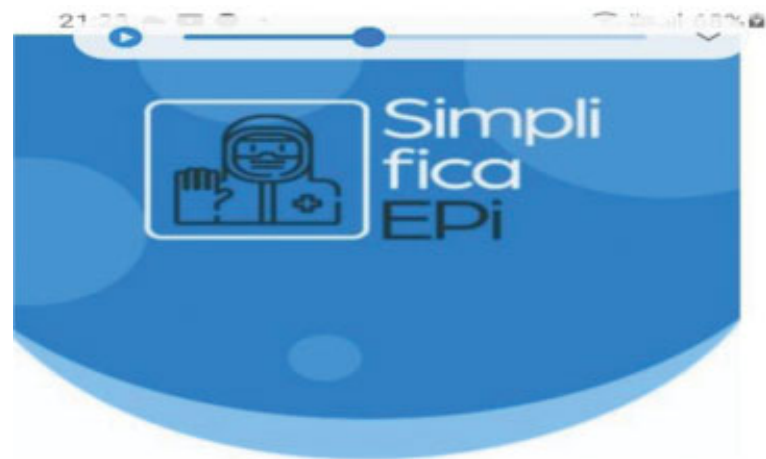

LESŌES POR DISPOSITIVOS MÉDICOS DURANTE A PANDEMIA PELA COVID 19

A pele é a primeira barreira de defesa contra as agressōes do meio ambiente e é frequentemente sujeita a forças mecânicas e químicas (SIVAMANI et al., 2003), pelo quê, suas características protetoras ficam alteradas, como é o caso da utilizaçāo continua de dispositivos médicos/EPIs. Isso se deve a fatores físicos, como a pressăo sustentada, forças de tensão. fricçăo e de atrito, bem como a umidade e a

temperatura, que estão diretamente associados ao desenvolvimento de Úlceras por Pressāo (UP), lesōes por fricçāo e quebras cutaneas. (SCHWARTZ et al. 2018).

III $\square$

$<$

a $\times 8 a$ th. $=\ldots$

- - as:rs

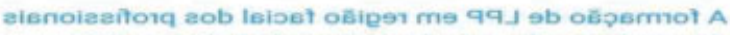
ab oau oloq sbenoiasso ò stromlevoe obùse sb

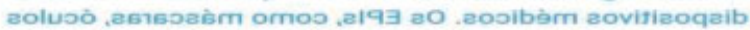

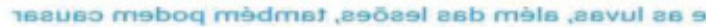

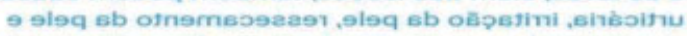

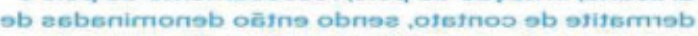

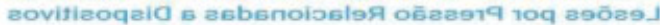
aooibòM
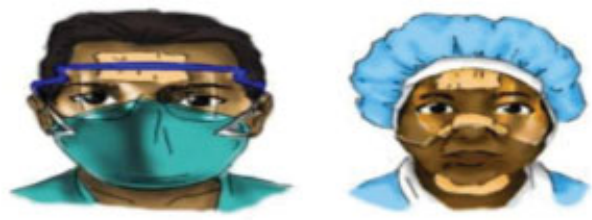

,eisiset aeาsoekmm asb otenosni vo obepnoloxq oeu 0

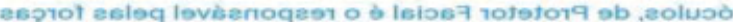

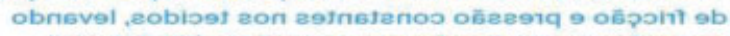

.. Is 19 HT

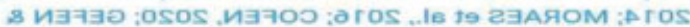
. $\cos$, y 3 zuo

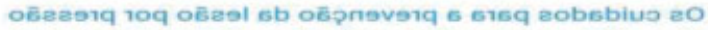

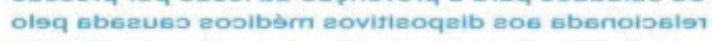
smsxs ob olsm roq abesiles7 19e meveb al9 sb aovisieoqeib eob otnemenoisieoqsi, sleq $6 \mathrm{~b}$ oineilb
$>$
C

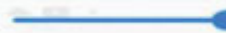

No mês de abril de 2016, o National Pressure Ulcer Advisory Panel anunciou uma mudança na terminologia de úlcera de pressão para lesão por pressāo, e também incluiu lesāo por pressāo relacionada a Dispositivo Médico. Esta lesāo resulta do uso de dispositivos concebidos e aplicados para fins de diagnóstico ou terapêutico, e caracteriza-se quando o profissional utiliza os EPIs e contrai lesăo durante o uso, conforme llustraçōes na figura 23 e reproduçăo de fotos na figura 24 e 25 a seguir. (RIETH et al., 2014: MORAES et al., 2016; ANVISA, 2020; COFEN, 2020; GEFEN \& OUSEY, 2020; MOURA et al., 2020; GREFEN et al., 2020).
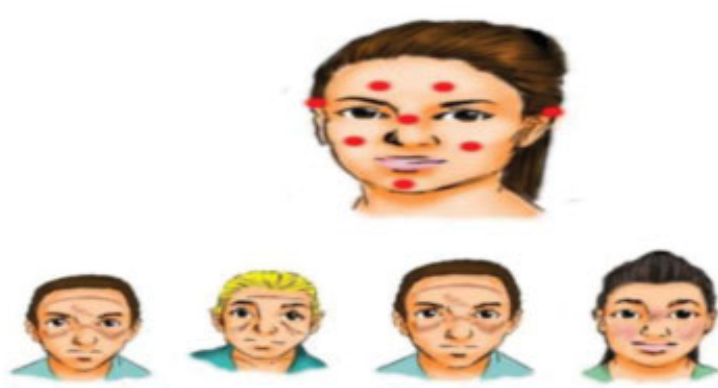

111

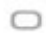

$<$

$$
2125 \text { a } 0 \text { - } 0 \text { covidapp.progm.net.br }
$$

Nesse sentido, estudo realizado pela APTFeridas (MOURA et al., 2020) sintetizou as medidas

preventivas para a lesâo por pressâo por dispositivo médico causada pelo uso do EPIs, as quais estão descritas a sequir:

1 - Uso de cremes e protetores-barreira e os oclusivos Eles desaceleram a transpiraçāo e reduzem a fricção sobre a pele do profissional, pois, com o tempo, a pele produz oleosidade. Existe também evidència cientifica que documenta a eficácia dos décidos gordos hiperoxigenados na prevençăo de lesăo por pressăo por dispositivo medico ocasionada pelo uso do EPIs.

2 - A utilização de cobertura (espuma de silicone. poliuretano transparente e hidrocoloide) de prevençăo de lesăo por pressăo decorrente de dispositivo médico por uso do EPIs, frequente na prática clínica, deve ser de nivel de evidência $\mathrm{B}$. O material de interface devo ser fino, năo promover traumas durante a remoçăo, absorver a umidade, ser adaptável ao contorno das estruturas da face, garantir a correta selagem da máscara. A figura 26, a seguir, apresenta os tipos de materiais utilizados em tratamentos de lesōes por EPIs.

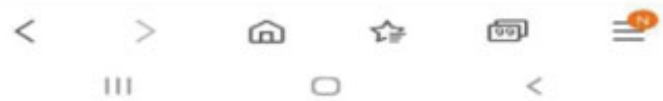

Fig. 6 Screens about preventive care for injuries caused by the inappropriate use of personal protective equipment. Pouso Alegre, MG, Brazil, 2020 . 
The limitation of the present study was the nonvalidation of the Simplifica EPI application, which is a future research perspective.

\section{Conflict of Interests}

The authors have no conflict of interests to declare.

\section{References}

1 Tan WJ, Zhao X, Ma XJ. A novel coronavirus genome identified in a cluster of pneumonia cases: Wuhan, China 2019-2020. China CDC Weekly 2020;2(Suppl 4):61-62. Doi: 10.46234/ccdcw2020.017

2 Zhu N, Zhang D, Wang W, et al. A novel Coronavirus from patients with pneumonia in China, 2019. N Eng J Med 2020:1-7. Doi: 10.1056/NEJMoa2001017

3 Paczek RS, do Espírito Santo DMN, Galvan C. Utilização de equipamentos de proteção individual em unidade endoscópica. Rev Enferm UFPE Online 2020;14:e243993

4 Rieth GH, Loro MM, Stumm EMF, et al. Uso de equipamentos de proteção individual pela enfermagem em uma unidade de emergência hospitalar. Rev Enferm UFPE Online 2014;8(02):365-371

5 Gefen A, Alves P, Ciprandi G, et al. Device-related pressure ulcers: SECURE prevention. J Wound Care 2020;29(Sup2a):S1-S52

6 Alves NF, Salomé GM. Aplicativo "SICKSEG" em plataforma móvel para a prevenção de lesões. Rev enferm UFPE. [Internet]. 2020 [acceso: 19/04/2020]; 14:e244152 Disponible en: https://periodicos.ufpe.br/revistas/revistaenfermagem/article/view/244152/35038

7 Salomé GM, Ferreira LM. Developing a mobile app for prevention and treatment of pressure injuries. Adv Skin Wound Care 2018;31 (02):1-6. Doi: 10.1097/01.ASW.0000529693.60680.5e

8 Salomé GM, Bueno JC, Ferreira LM. Multimedia application in a mobile platform for wound treatment using herbal and medicinal plants. J Nus UFPE online. [Internet]. 2017 [acceso: 22/03/2020]; 11(Sup11):4579-88. Disponible en: https://periodicos.ufpe.br/revistas/revistaenfermagem/article/view/231197

9 Galvão ECF, Püschel VAA. [Multimedia application in mobile platform for teaching the measurement of central venous pressure]. Rev Esc Enferm USP 2012;46(Spec No):107-115www.ee. usp.br/reeusp/

10 Barra DCC, Paim SMS, Dal Sasso GTM, Colla GW. Métodos Para Desenvolvimento De Aplicativos Móveis Em Saúde: Revisão Integrativa Da Literatura. Texto Contexto Enferm 2017;26(04): e2260017. Doi: 10.1590/0104-07072017002260017

11 Mendes KDS, Silveira RCPC, Galvão CM. Revisão integrativa: método de pesquisa para a incorporação de evidencias na saúde e na enfermagem. Texto Contexto Enferm 2008;17 (04):758-764

12 Santos CMC, Pimenta CAM, Nobre MRC. The PICO strategy for the research question construction and evidence search. Rev LatinoAm Enfermagem. 2007;15(03):508-511. Doi: 10.1590/s010411692007000300023.

13 Agency for Health Care Research and Quality. Quality Improvement and monitoring at your fingertips [Internet]. Rockville: Agency for Healthcare Research and Quality; 2016 [cited 2019 mar 22]; Available from: http://www.qualityindicators.ahrq.gov

14 Pereira FG, Silva DV, Sousa LM, Frota NM. Building a digital application for teaching vital signs. Rev Gaúcha Enferm 2016; 37(02):e59015. Doi: 10.1590/1983-1447.2016.02.59015

15 Salomé GM, Bueno JC, Ferreira LM. Multimedia application in a mobile platform for wound treatment using herbal and medicinal plants. J Nurs UFPE Online. [Internet] 2017;11:4579-4588

16 Ministério do Trabalho e Emprego (Br) Portaria $n^{\circ} 485$, de 11 de novembro de 2005. Aprova a norma regulamentadora $\mathrm{n}^{\circ} 32$ (Segurança e saúde no trabalho em estabelecimentos de saúde) [Internet]. Diário Oficial da República Federativa do Brasil, Brasília (DF); 2005 [cited 2020 mar 20]. Available from: http:// sbbq.iq.usp.br/arquivos/seguranca/portaria485.pdf

17 Silva LS, Machado EL, Oliveira HN, Ribeiro AP. Condições de trabalho e falta de informações sobre o impacto da COVID-19 entre trabalhadores da saúde. Rev Bras Saúde Ocup 2020;45:e24. Doi: 10.1590/2317-6369000014520

18 Kantor J. Behavioral considerations and impact on personal protective equipment use: Early lessons from the coronavirus (COVID-19) pandemic. J Am Acad Dermatol 2020;82(05): 1087-1088. Doi: 10.1016/j.jaad.2020.03.013

19 Oliveira HC, Souza LC, Leite TC, Campos JF. Personal Protective Equipment in the coronavirus pandemic: training with Rapid Cycle Deliberate Practice. Rev Bras Enferm 2020;73(73, Suppl 2) e20200303. Doi: 10.1590/0034-7167-2020-0303

20 Cunha DR, Salomé GM, Massahud MR Junior, Mendes B, Ferreira LM. Development and validation of an algorithm for laser application in wound treatment. Rev. Latino-Am. Enfermagem. [Internet]. 2017 Dec [cited Aug 26, 2019];25:e2955. Available from: http://www.scielo.br/pdf/rlae/v25/0104-1169-rlae-25-e2955.pdf

21 Carvalho MRF, Salomé GM, Ferreira LM. Construction and validation of algorithm for treatment of pressure injury. J Nurs UFPE Online 2017;11(10):4171-4183

22 Salomé GM, Rocha CA, Miranda FD, Alves JR, Dutra RAA, Tenório AG. Algoritmos para prevenção e tratamento de dermatite associada à incontinência. ESTIMA, Braz. J. Enterostomal Ther 2020; 18:e1320. Doi: 10.30886/estima.v18.837_PT 